\title{
THE LEGAL REFORM OF THE WAQF LAW RESOLUTION BASED ON PANCASILA
}

\author{
${ }^{1}$ Islamiyati, ${ }^{2}$ Ahmad Rofiq, ${ }^{3}$ Ro'fah Setyowati, ${ }^{4}$ Dewi Padusi Daengmuri \\ ${ }^{1,3}$ Faculty of Law, Diponegoro University Semarang \\ ${ }^{2}$ Walisongo State Islamic University Semarang \\ ${ }^{4}$ Law Science Doctoral Program, Diponegoro University Semarang \\ islamiyati@yahoo.co.id
}

\begin{abstract}
Nowadays, there are still some shortages in the rule of law of the waqf disputes resolution, therefore a lot of waqf disputes have not be solved, and moreover it has no justice value since it does not protect the rights of disputing parties. Why the legal renewal of waqf disputes resolution based on Pancasila is important? The urgency is as the media for the enforcement and the law enactment of the waqf dispute resolution based on Pancasila. This research is field research, and the approach method is juridical empirical. The result of the research is to explain that the legal reform of waqf dispute resolution is important because the waqf disputes always develope based on the sociocultural development of the society. Besides, it also saves the waqf assets, gives the values of justice and certainty, makes the rule of the law not rigid and closed, can finish the waqf disputes, and makes waqf meaningful in the society. The legal reform of waqf disputes resolution which is based on Pancasila means making the policy that includes determining and deciding the rules of waqf dispute resolution, hence it will be suitable with the direction of national development based on Pancasila.
\end{abstract}

Keywords: The Legal Reform; Dispute Resolution; Waqf; Pancasila; Global

\section{Introduction}

Waqf is the action of utilization diversion of the treasure from the individual property to the public for the social interest which does not contradict with the Islamic law. The moslem do waqf because they understand that waqf is one worship action which has social function. Beside giving a reward for wakif, it also givesa lot of benefits for the society, from the view of education, from the preparation of worship facility, public facility, health, and also the supply of job vacancy. How big is the benefits of waqf in the society so that the waqf doing which is based on Islamic law is called Jariyah charity. It is the charity that its reward will keep flowing during it gives the benefits for other people. ${ }^{1}$ It is relevant with Muhammad SAW Hadith, told by Abu Daud, that means: from Abu Hurairah ra, said: In fact Nabi Muhammad SAWsaid: "if the human beings rest in peace, hence their charity is cut, except for three things, namely; jariyah charity, meaningful knowledge and good kids who pray for their parent". 2

\footnotetext{
1 Sayyid Abi Bakr bin Sayyid Muhammad, I'a $>n a h$ al-T\}alibi $>n$, Juz III, (Beirut: Da>r al-Kutub al-Ilmiah, without year), 272-273.

2 Ibid.
} 
Those previous jariyah charity motivates Islamic people in doing waqf . As a result, the waqf doing in Indonesia developes significantly. According to the data of The Waqf Enachment Directorat of Religion Ministry, in 2016, the national land waqf assets reached 4,359 billion square in 435.768 locations in the whole of Indonesia. In 2017, it reached 4,364 billion square and in 2018 it reached 4,4 billion square. ${ }^{3}$ The amount of national assets can help the goverment in supplying the public facilities.

The assets of land waqf which always relate to the public interest and have economic value are very susceptible to the disputes. The objects of disputes are waqf treasures. Whereas the disputing parties can be happen between the society and nadzir (waqf management) wakif (someone doing waqf) with nadzir, and nadzir with the heirs of wakif. ${ }^{4}$ The previous disputes have to be solved based on the existing law basic.The resolution of waqf disputes has been explained in Islamic Law. It is done through discussion for the peace, ${ }^{5}$ mediation ${ }^{6}$ and justice judge. $^{7}$ It is strengthened by the rule of the law determined by the nation in the Article 62 of Waqf Rules which explains that the procedures of waqf dispute resolution, are as the following;

3 BPS, "Persentase penduduk miskin Maret 2018 turun menjadi 9,82 persen," Badan Pusat Statistik. Accessed December 24, 2018, time 11.39 pm. https://www.bps.go.id/pressrelease/2018/07/16/1483/persentase-pendudukmiskin-maret-2018-turun-menjadi-9-82-persen.html.

4 Islamiyati dan Dewi Hendrawati, The implementation of Article 62 The Rules No. $41 / 2004$ in waqf dispute resolution in Central year 2016, The Report of a research result is financed by the donation outside from APBN FH UNDIP (National Budget of Law Faculty in Undip) (Semarang: Faculty of Law, Diponegoro University, 2016), 104.

5 The resolution way through discussion in order to reach a peace is explained in Al'Quran Surat Asy-Syura of paragraph 48, that means; "Dan (bagi) orang-orang yang menerima (mematuhi) seruan Tuhannya dan mendirikan shalat, sedang urusan mereka diputuskan dengan musyawarah antara mereka; dan mereka menafkahkan sebagian dari rizki kami berikan kepada mereka" (At-Tanzil, Al-Qur'an and the translations Juz 1 up to 30 (Transliterasi), Bandung, Sinar Baru Algesindo, 2012, page. 1025.) Although that previous paragraph is aimed for a certain dispute, yet it can be concluded that the paragraph can become general principal in dispute resolution, including waqf resolution.

6 Mediation is the way of dispute resolution through third party (mediator), in Islamic law is called tahkim, a dispute resolution with a help of the third party (hakam). The resolution way through mediation/tahkim is explained in Al-Qur'an of An-Nisa' letter, paragraph 35, that means; "Dan jika kamu khawatir terjadi persengketaan antara keduanya, maka kirimkan seorang juru damai dari keluarga laki-laki dan juru damai dari keluarga perempuan. Jika keduanya (juru damai itu) bermaksud mengadakan perbaikan, niscaya Allah memberikan taufik kepada suami isteri itu, Allah Maha Mengetahui dan Maha Teliti” (Ibid, 162).

7 The court judge is the state official that has an authority in solving dispute handled. The judge has a atask to decide and determine the dispute which is entered the court. Islamic law explains in order to appoint judge in dispute resolution, in Al Qur'an explains that Allah is the best judge who decide human disputes. The teaching of Allah stated in Al Qur'an can be used as a reference and guidance in relation to the judge in the Court. Al Qur'an in Al Nisa letter paragraph 135 explains about the obligation of judge in order to enforce the justice. Al Qur'an in Al Nisa letter paragraph 135 "Wahai orang-orang yang beriman, jadilah kamu orang-orang yang benar-benar penegak keadilan, menjadi saksi karena Allah SWT. Biarpun terhadap dirimu sendiri, atau Ibu Bapakmu dan Kaum Kerabatmu, jika Ia kaya atau miskin, maka Allah lebih tahu kemaslahatannya.Maka janganlah kamu mengikuti Hawa Napsu karena ingin menyimpang dari kebenaran. Dan jika kamu memutar balikkan (kata-kata) atau enggan menjadi saksi, maka sesungguhnya Allah SWT. Adalah Maha mengetahui segala apa yang kamu kerjakan"(Ibid, 170). 
(1) the resolution of waqf disputes is done through discussion in order to get one agreement. (2) If the resolution of waqf disputes as stated in the first verse (1) is not successful, therefore the dispute can be finished through mediation, arbitration, or the court (Religion Court).

The research of Upi Komariah (2014) about Penyelesaian Sengketa Wakaf di Pengadilan Agama, explains that the cause of waqf disputes are the existence of spoken waqf which bases waqf doing on the mutual trust only, hence there is no authentic proof of doing waqf. As a result it can cause the disputes. If the efforts of solving diputes through discussion, mediation, and arbitration do not work, so that the dispute resolution can be done through Religion Court. ${ }^{8}$ The data explains that the waqf law which comes from the principles of Islamic Law has not have the power and the certainty of law, as a result it causes the waqf disputes.

The waqf disputes resolution in the society has not been wholly appropriate with the rules of law. The resolution of waqf disputes is not suitable with the basic or the principle of discussion. It can be showed from the example of waqf dispute resolution in Wonolodari village office, Mijen Sub district, Semarang Regency about the acquisition of waqf property by the waqf heir (grandchildren). PPAIW does not ask the grandchildren (prosecutor) to do discussion, but PPAIW decides the dispute resolution by givinga Charity Fund $\mathrm{Rp} 10$ million to the grandchildren of the heir and asks him to keep silent and does not consider about the status of waqf land that ever been given by his grandfather anymore. ${ }^{9}$ That Nadzir's decision has broken up the principle of discussion, since he has not asked the disputing party to discuss the problem together.

Ismawati in her research about the resolution of waqf dispute of Bondo in Masjid Agung Kauman Semarang, finds the condition that the process of waqf dispute resolution has not been suitable with the Article 62 of the Waqf Rules. In the case of the loose of Bondo Masjid Agung Semarang, the resolution of waqf dispute is by using class action. It means that the society tries to force the party who dominates the waqf treasure to return waqf propherty to the society. ${ }^{10}$ Based on the previous data, it shows ineffective and unfair understanding of waqf dispute

8 Komariah, "Penyelesaian Sengketa Wakaf Di Pengadilan Agama," Jurnal Hukum dan Peradilan 3, No. 2 (2014): 117-126, Bandung Religious Court, 1.

9 Islamiyati and Dewi Hendrawati, The Implementation of Article 62 The Rules No. $41 / 2004$ in waqf dispute resolution in Central Java, Report of Research report financed by the donation outside APBN FH UNDIP (Semarang: Faculty of Law, Diponegoro University, 2016), 118.

10 Ismawati, Penyelesaian Sengketa Tanah Wakaf Studi Terhadap Tanah Wakaf Banda Masjid Agung Semarang, Thesis (Semarang: Magister Ilmu Hukum, Diponegoro University, 2007), 8. 
resolution efforts. Moreover it is not based on the correct discussion and mediation and it does not use the law as the society need. ${ }^{11}$

Based on the explanation previously, it shows legal issue as the state of the art in this research. The legal problem between the procedure of waqf dispute resolution as stated in the Section 62 of Waqf Rules (dassollen) and the implementation of procedure in waqf resolution in the society which is not suitable with the law hence it contradicts with Pancasila (das sein). This such condition becomes the main reason why the research of waqf dispute resolution should be done. The problem is why the Legal Reform of waqf dispute resolution based on Pancasila in the global era is very important to be done? Besides how is the concept of its legal renewal approach? The research is aimed to explain and to analyze the reason of the legal reform of waqf dispute resolution based on Pancasila in the global era and to describe its legal renewal approach concept. The benefit is to develop the legal reform of waqf disputes in order to realize fair law based on the values of Pancasila.

\section{Methods}

This research is socio-legal research, because it analyzes the problem of waqf dispute resolution in the society, and its reason of the legal reform. Besides, it also explains the legal reform of waqf dispute resolution based on Pancasila and its legal reform approach concept used. This research is a qualitatif research with the goal to develop the theory concept which is based on the data and the source of the research. The approach concept uses empirical juridical. Juridical means the research that try to search some things in relation to the basic law of the rules being used, namely the Rules No. 41/2004 About Waqf, Govermental Rule No. 42/2006 about the Rules of Waqf Implementation. Empirical is the research about the implementation of the rule of waqf dispute resolution in the society, the relation of the law with the society, and how the problems and the legal reform in relation to the rule of the law of waqf dispute resolution.

The research data needed are primary and secondary data. The primary data comes from the research object namely Central Java. The location sample of the research include Semarang Regency and Semarang City, Demak Regency, Kendal and Klaten. The primary data is obtained from the interview with expert speaker. Whereas the secondary data is obtained through the library study and documentation. The secondary data includes primary, secondary and tertiary

11 Soedarto, Hukum dan Hukum Pidana (Bandung: Alumni, 1986), 151. 
law materials. The research data will be analyzed descriptive analytically. It means that the result of the research will be explained, and analyzed in order to answer the problems of the research. The data processing is done by examining, organizing, conceptualizing or arranging the data, synthesizing, analyzing, editing, coding, and concluding. Therefore the objectives and the benefits of the research will be reached.

\section{Result and Discussion}

This research is a development of the results of research carried out by Islamiyati and Dewi Hendrawati about "Implementasi Pasal 62 UU No. 41/ 2004 dalam Penyelesaian Sengketa Wakaf di Jawa Tengah tahun 2016". In this study explained that the resolution of waqf disputes in Central Java in general use a method that is not fully in accordance with Article 62 of the Waqf Law. More people use non-litigation methods in the resolution of waqf disputes, namely deliberations $(23 \%)$ and mediation $(60.8 \%)$. However, this method does not comply with the correct principles and principles, for example; the parties to the dispute were not consulted but were immediately decided by nadzir, and the mediator was instrumental in resolving the waqf dispute. This was done because there was no legal certainty regarding the practical instructions for the resolution of waqf disputes. ${ }^{12}$ Therefore, it is very important to conduct research on the renewal of waqf disputes based on the values of Pancasila, considering that Pancasila is the ideals of the Indonesian state law, all laws must be constitutional, must not conflict with Pancasila as the ideal foundation of the state.

Research on waqf disputes has been carried out by several researchers, all of which will be explained through the following table:

Table .1.

\section{Review of Waqf Dispute Research Library}

\begin{tabular}{clll}
\hline No. & Researcher Name & Title Research & Research Results \\
\hline 1. & $\begin{array}{l}\text { Nur Fadhilah } \\
(2011)\end{array}$ & $\begin{array}{l}\text { Waqf Land Dispute and } \\
\text { its Settlement Strategy. }\end{array}$ & $\begin{array}{l}\text { The community has not fully paid } \\
\text { attention to the regulations in the } \\
\text { implementation of waqf especially for } \\
\text { those who do or give waqf. This } \\
\text { causes the unclear status of waqf both } \\
\text { legally and administratively, so that it } \\
\text { becomes the cause of waqf dispute. } \\
\end{array}$ \\
& $\begin{array}{l}\text { The settlement through litigation if the } \\
\text { settlement through non-litigation }\end{array}$ \\
\hline
\end{tabular}

12 Islamiyati dan Dewi Hendrawati, Op. Cit, 90. 
2. Ibrahim Siregar (2013)

3. Urip Santoso (2014)

4. Syufa'at (2018)

\section{5}

\begin{abstract}
Izzati Rizki
(Skripsi 2018)
\end{abstract}

Settlement of Waqf The Social Historical Approach of Islamic Law

Legal Certainty on Waqf Land Ownership Rights

Application of Mediation Procedures in Settlement Waqf Dispute in the Religious Courts Disputes in Indonesia:

(deliberation and mediation as well as arbitration) is not successful. ${ }^{13}$

Issues raised at the beginning of the Islamic period and contemporary cases of waqf disputes caused by social change; a shift in the value and order of society, and the absence of written evidence that states that the status of an asset as an object of waqf. The solution uses a custom that occurred in Indonesia in the past few decades, namely deliberations led by religious leaders and local communities. $^{14}$

Land Waqf Rights are proven by Akta Ikrar Wakaf made by (PPAIW). Land Waqf Waqf must be registered with BPN to issue Waqf Certificate as proof of waqf land. The certification of waqf land which is authentic evidence of the occurrence of waqf actions can minimize future waqf disputes, if the wakif dies. ${ }^{15}$

PERMA 1 Tahun 2016 a bout Mediation Procedures in the Court explains that every judge, mediator, parties and / or attorney is required to follow the procedure of dispute resolution through mediation. Case investigating judges who do not order the parties to mediate so that the parties do not mediate have violated the provisions of the legislation governing mediation in the Court. ${ }^{16}$

Effectiveness

of Waqf land dispute Baitul Qudus Mediation in the Mosque on Gebanganom, Genuk Sari, Settlement of Waqf Genuk, Semarang Regency, which Disputes (Case Study of the Waqf Land of the Baitul Qudus Mosque on Jalan Gebanganom, Genuk Sari, Semarang Regency, Central Java) was pursued using a mediating pathway has not been effective, due to several factors, including: a) complicated level of cases; b) low motivation to reach agreement; c) low commitment or one party does not have good faith; d) cost aspects or lack of funding sources; e) disputes relating to basic or ideological

13 Nur Fadhilah, "Sengketa Tanah Wakaf dan Strategi Penyelesaiannya," Jurnal Hukum dan Syari'ah De Jure, UIN Malang, (2011):15.

14 Ibrahim Siregar, "Penyelesaian Sengketa Wakaf Di Indonesia: Pendekatan Sejarah Sosial Hukum Islam,” Jurnal Miqot 36, No. 1 (2012): 1.

15 Urip Santoso, “Kepastian Hukum Wakaf Tanah Hak Milik,”Jurnal Perspektif XIX, No. 2 (2014): 1.

16 Syufa'at, "Penerapan Prosedur Mediasi Dalam Penyelesaian Sengketa Wakaf di Pengadilan Agama,"Jurnal Volksgeist 1, No. 1 (2018): 21. 
principles; f) unequal strength of the parties; g) unskilled mediators; h) mediation meeting rooms that are not supportive; i) time efficiency. ${ }^{17}$

Based on the explanation above, it shows that research on renewal of the resolution of waqf disputes based on Pancasila has never been carried out by a previous research.

\subsection{The Reason of Legal Reform in Waqf Dispute Resolution Based on Pancasila}

The legal reform by William Hulburt is meant as; Law reform or legal reform is the process of examining existing laws, and advocating and implementing changes in a legal system, usually with the aim of enhancing justice or efficiency. ${ }^{18}$ The explanation is that legal renewal (law reform) is the process of examining the existing law, advocating and implementing the changes in the law system in order to improve the justice and the efficiency of law, so that the law can be implemented in the society. The legal reform is started by critisizing the existing Rules. And then the implementaton in the society is examined. If it is not efficient or it can not be enforced, therefore the law can be reformed.

In relation to the legal reform of waqf dispute resolution, it is begun by the process of examining the existing law. The law is conceptualized as the written law determined by the national institution. The birth of Waqf Rules is one big agenda in the legal reform procedure of the waqf dispute resolution as explained in the Article 62 of waqf Rules. This section has been perfected the clause of article 226 KHI President Instruction No 1/1991 which explains that the procedure of waqf dispute resolution is only through the litigation pathway, namely Religion Court.

The existence of article 62 of waqf Rules has given the direction how is the procedure of waqf dispute resolution from the simple way up to the law process, namely PA Judge. This waqf Rule is the result of human being thought objectively and rationally. Objectively means suitable with the condition which shows that the law is exist and it is really practiced in the society. Whereas Rational means that waqf Rules is the result of human being thought with the following condition.

17 Izzati Rizki Annisa, Efektivitas Mediasi Dalam Penyelesaiaan Sengketa Wakaf (Studi Kasus Tanah Wakaf Masjid Baitul Qudus Di Jalan Gebanganom Genuk Sari Semarang Jawa Tengah), Skription,Ahwal AsSyakhsiyah Department, Faculty of Sharia and Law, Walisongo State Islamic University, (Semarang: Walisongo State Islamic Universiy, 2018), vii.

18 Hurlburt William H., Law Reform Commissions in the United Kingdom, (Australia and Canada: Juriliber, 1986), 3. 
The article 62 of waqf Rules explains that the waqf dispute resolution can be done through two pathways, such as the following; ${ }^{19}$

a. Non-litigation Pathway is the resolution of waqf dispute from out of the court pathway, through discussion between the disputing parties, in order to make a peace. If the discussion does not work, therefore the resolution is done through mediation, namely the dispute resolution by including the third party who is called mediator who becomes the mediator, which has a task to give alternative of dispute resolutionfor manyparties. ${ }^{20}$ If the mediation is not succesful, hence arbitration can be done. It is the effort of dispute resolution by involving the third party (arbriter) whose has the specific knowledge about the problems being disputed. The Arbriter can be chosen bythe disputing parties because they believe that arbriter has a knowledge andenough backgroud about the problems honestly and fairly. ${ }^{21}$

b. Litigation pathway is the effort of dispute resolution through The Court Instituion pathway which has an authority to solve waqf dispute. This pathway is done if the parties can not solve the waqf dispute by using non-litigation pathway. They submit the effort of the waqf dispute resolution through the process of procedural law. Related to the competence of adjudical violation of waqf, it is regulated in section 49 of the Rules 7/19898 N0. 3/2006 which explains that the Religion Court has a duty and an authority to examine, decide, and finish the dispute in the first level among Islamic people in the section of : (a) marriage; (b) beneficiary, (c) will; (d) grant; (e) waqf; (f) zakat; (g) infaq; (h) shadaqah; and (i) syari'ah economy. From the article, it is explained that The Religion Court has a competency in order to solve the waqf dispute proposed. The basic law that is used in order to solve the waqf dispute through litigation pathway is the Rules of Religion Court (UUPA) No.7/1989 jo The Rules No.4/2004 about the Supreme Justice. The procedural law, generally, uses the procedural law of General Court, except it is specifically regulated in UUPA (Article 54 UUPA).

The waqf dispute resolution which is done by non-litigation pathway is done by using customary law which is existed in the society as a basis, where that law comes from Islamic Law,namely the discussion in order to get the peace and mediaton. That previous Islamic Law is global. It has not described its detail regulation. Besides, they have no written rule determined by the national institution therefore the rule used is based on the close habit which does not

\footnotetext{
19 The explanation of article 62 The Rules No. 41 Year 2004.

20 T.O. Ihromi (Ed.), Antropologi Hukum:Sebuah Bunga Rampai, (Jakarta: Yayasan Obor Indonesia, 2001), 209210.

21 Ibid.
} 
contradict with the Islamic Law. This condition causes the rule of waqf dispute resolution has no power of law which can protect the disputing parties.

The waqf dispute resolution by using non-litigation pathway uses the law regulation as stated in Article 62 of Waqf Rules No. 41/2004. However, those waqf Rules only describe globally or generally. It does not expalin in detail about the discussion, mediation and arbritrary. So far, the nation has had the rule of waqf dispute resolutionthrough non-litigation pathway, namely the Rules No. 30/1999 about the Arbritation and ADR (Alternative Dispute Resolution) the Alternative of Dispute Settlement. The Article 1 (10) of this Rule explains that waqf dispute Resolution through non-litigation is done by consultation, negotiation, mediation, conciliation or the expert assestment. However, in this rules does not mention the clause specifically of waqf dispute Resolution. In the contrary, waqf doing has their own characteristic, such as; the waqf treasure is everlasting and it may not be lost, the use of waqf treasure is for social interest, and waqf doing has values of worship and social. In conclusion, The Rules No. 30/1999 can not be implemented in waqf dispute resolution.

In fact, society has their own way in solving the waqf dispute which is based on Islamic Law. The manner used comes from the practice of scholar/ clerics or PPAIW in waqf dispute resolution. According to the interview with PPAIW, ${ }^{22}$ it explains that the task of PPAIW as the national instituion is giving service of waqf doing in the society. PPAIW does not only as a mediator of waqf dispute resolution but alsoit is solving the waqf dispute. The reasons are; a) The society needs the resolution of wafq dispute, because the knowledge of waqf in the society is very low; b) There is a few society resources in solving the dispute, hence they ask for help to PPAIW in relation to waqf dispute resolution. If it is not done, it is worried that the dispute is not solved; c) In relation to the religion teaching, PPAIW often uses the religion approach in waqf dispute resolution; d) As the form of waqf service because the society needs it; e) In order to save waqf treasure; f) PPAIW roles as the enforcer institution of waqf law.

Based on the previous explanation, it can be analyzed that the waqf dispute resolution for PPAIW is considered as expert people in accordance to waqf law. If the waqf dispute occurs, PPAIW's duty is to solve that dispute hence the waqf dispute can be solved fairly, the waqf treasures can be saved and moreover the waqf law can be enforced in the society. In conclusion, the applicable law is the law that is alive in the society. They does not use the rules that is regulated by the nation namely the Rules No. 30/1999.

\footnotetext{
22 Interview with Darun, The Religious Affairs Office Head of Banyumanik subdistrict, August $6^{\text {th }} 2019$, Time $14.30-16.00$
} 
Starting from the desciption previously, it can be understood that the law problems of waqf dispute resolution, namely; Article 62 of Waqf Rules only explains the procedure of waqf dispute resolution generally. It does not explain in detail about the discussion, mediation and arbritation. Moreover there is no law certainty about the practical guide in the procedure of waqf dispute resolution. Besides, the rules of dispute resolution as stated in the Rules No. 30/1999 can not be implemented in the society because the waqf doing has specific characteristic and so far the society is applying existing law which become a habit in waqf dispute resolution.

The law problems about the procedures of waqf dispute resolution above, effect to the ineffectiveness of the rule in Article 62 of waqf Rule about the procedure of waqf dispute resolution. For that reason, the legal reform of waqf dispute resolution is needed. It is the effort in order to change or to perfect or to change the rules of law in relation to waqf dispute resolution, for national law as well as for law in the religious institution. It is needed because the problems of waqf disputes always develope in accordance with sociocultural thought development of the society. ${ }^{23}$

The legal reform of waqf dispute resolution is very important to be done in order that waqf dispute can be solved and it does not contradict with the principles and the basics of waqf dispute resolution law. In the global era, the law system always move extendly to the larger scope. It does not only include the scope of local but also national,transnational, even International. Furthermore, the development of waqf law has been spread up in the whole world. It makes the waqf problem complex and varied, if there is no legal reform in the procedures of waqf dispute resolution. As a result, a lot of assets can not be saved. The legal reform is used as a tool to adapt with the developing law, hence the rule of the law of waqf dispute is not rigid, closed and authoritary. $^{24}$

For that reason above, there are three kinds of law reform directions in Indonesia, such as the following; ${ }^{25}$ a) The direction of comprehensive development in waqf dispute resolution. It does not only based on Madzab Iman Syafi'i, but also Madzhab Imam Hanafi. The procedure of waqf dispute resolution is directed to the law that able to protect the disputing parties, to save waqf treasures, and to enforce waqf law. For that reason, the Islamic Law that is based on Fiqh of madzhab scholars should be constructed with the national policy through the reconstructing of rules of the law that is appropriate with the needs of the society. Hence it can realize the law

\footnotetext{
23 Mochtar Kusuma Atmadja, Hukum, Masyarakat, dan Pembinaan Hukum Nasional(Jakarta: Bina Cipta, 1976$), 6$.

24 Andreassen in Sulistyowati Irianto, Op. Cit., 24-37.

25 Miftahul Huda, Arah Pembaharuan Hukum Wakaf di Indonesia, Jurnal Studi Keislaman16, No. 1 (2012).
} 
certainty without contradicting with the principles of Islamic Law; b) The development of waqf dispute resolution to the more integrated waqf management. It means that the legal reform of waqf dispute resolution is done systematically through a lot of activities orderly. There are 2 processes used, namely the process of guiding and the process of preparing job facilities in the form of facilities and infrastructure. ${ }^{26}$ The direction of reform is done in order to anticipate the waqf dispute in the next time. It has been done starting from waqf doing up to the managing waqf and reporting waqf by nadzir in giving service of waqf. The goverment has already anticipated it too by creating the waqf certificate that their requirements of implementation should be fulfilled from registration of waqf until the management of waqf treasures. In this process, the goverment has efforted to supply the facilities in the form of the ease of registration and the exemption of financing waqf land certificate; c) The direction of legal renewal of waqf dispute resolution relates to the waqf institutions which manage waqf treasures. It is aimed to strengthen the capacity of waqf building in Indonesia.The waqf institutions in Indonesia have been developed in order to serve the society in doing waqf, for example; PPAIW which is exist in KUA Office), Religious Affair of the subdistrict, BWI of Regency and province, LKS-PWU who serve the implementation of cash waqf, BASYARNAS (National Syariah Arbitrary Body) as an institution which has an authority to solve syariah disputes), ${ }^{27}$ and religion Court that solve waqf dispute litigationally.

Based on the explanation about the direction of legal reform of above waqf disputes, it can be analyzed that the direction of the reform point (a) and point (c) have not been implemented. Hence the technical guidance about the procedures of waqf dispute resolution through nonlitigation has not been explained in detail in the rule of the law. As a result there is still a legal vacuum. Moreover, the institution of waqf dispute resolution has not been considered successful in solving waqf disputes. Hence the direction of legal reform of waqf dispute resolution is a long journey in order to implement the next law for the enforcement of fair waqf law in the society.

One step used is that the implementation of legal reform of waqf dispute resolution based on Pancasila. It is an effort in order to overhaul the rules of the law hence it has Pancasila legal system. Pancasila legal system is the legal system that integrate many kind of interest values, social value and justice concept into one prismatic legal ties, by taking their positif elements and

26 John D. Millet in Siswanto.

27 However, the existence of BASYARNAS has not able to finish waqf dispute through non-litigation, because that institution is only located in Central Jakarta, whereas most of waqf dispute happened in the area. The cost for dispute resolution is considered too expensive in perspective to waqf dispute aimed for social interest. 
then laid them in the balance, The balances are as the following ${ }^{28}$; a) Balance between individualism and the collectivity; b) Balance between rechstaat and the rule of law; c) Balance between the law as a tool to develope and the law as a mirror of values which are alive in the society; d) Balance between the religion state and secular state.

The relationship between the legal reform of waqf dispute with the legal system of Pancasila can be explained that the nation needs to form the rules of waqf dispute resolution as an implementation that Indonesia is a law nation. The aim is to form the law certainty which has a function to give law protection for disputing parties and to guide in waqf dispute resolution for the society who need them. Formulation of the rules about the procedure of waqf dispute resolution should combine the balance between religion law and the nation law. One regulation of the law material comes from the procedure of waqf dispute resolution practiced in the society and becomes the law that alive in the society. Therefore, there will be a balance between the law as mirror of the values existing in the society.

The legal reform of waqf dispute resolution based on Pancasila should be able to implement the prismatic law which becomes the legal system based on Pancasila whose characteristic as the following: ${ }^{29}$ a) Family concept, It means that the nation ensure the rights of individual and Human Rights, but it still gives a priority to national interest; b) Justice and certainty concept. It means the combination of positif side of many law systems in order to give the certainty of law based on the justice.; c) Religious nation stage concept. It means that the legal system based on the belief to Belief in The One and only God. It gives freedom and protection for the religious people to do their religious teaching based on their belief; d) Combined concept between the law as the mirror of existing values in the society and the law that direct the people to the development of ideal law; e) Unity tied concept. It aims to unity Indonesia whose has various culture, tradition, religion, tribes and etc.

In fact, the arrangement of procedure regulation of waqf dispute resolution should contain the following elements; a) It contains family concept which ensure the rights of wakif in doing waqf,including the obligation of heirs to waqf treasures and ensure the save of waqf treasure. As a result ewaqf law can be enforced fairly in the society; b) It does not contradict with principles of Islamic Law as the basic rules in doing waqf and also it protects and gives the freedom of

28 Moh. Mahfud., Membangun Politik Menegakkan Konstitusi (Jakarta: Rajawali Pers, 2010), 32.

29 Arief Hidayat, "Negara Hukum Pancasila (Suatu Model Ideal Penyelenggaraan Negara Hukum)", Prosiding dalam Konggres Pancasila IV, Strategi Pelembagaan Nilai-Nilai Pancasila dalam Menegakkan Konstutusionalitas Indonesia, (Yogyakarta: PSP UGM, 2012), 60-61. 
Islamic people in doing waqf; c) It compiles between the law as a mirror of existing values in the society and the law that direct the people to the development of ideal law; d) The objective of regulation forming is aimed to reach the unity and the national unity.

The law based on Pancasila is used as a tool to make a balance among some interests hence conflict or violation of law can be finished. ${ }^{30}$ The existence of Pancasila shows that Indonesia embrace the understanding of national law. In other word the nation acknowledge the basic human rights and obligation, and moreover the nation makes the rules of the law which makes a possibility to ensure the save, orderly life, and peace for society. The legal reform of waqf dispute resolution based on Pancasila reflects the values in Pancasila, namely the divinity value, human value, unity value, social value and justice value. Those values are adapted with the policy direction of national development and it is hoped that they can support the effort of reaching national goals as stated in the Introduction of The Indonesia Republic Nation Rule of 1945 pharagrap IV, namely: protect all Indonesian people and all Indonesian blood spilled, improve the public prosperity, enrich the life of the nation, and participate in carrying world order, that is based on the independence, eternal peace, and social justice.

The existence of waqf dispute resolution law is hoped to be able to solve waqf disputes and to protect the disputing parties and also to ensure the national Unity and Integrity. The waqf disputes that have been solved succesfully, will save the waqf treasures and moreover it can be implemented in the society hence it can realize social welfare and enrich the life of the nation. Furthermore, it can help the goverment in the effort to gain the world order because the use of waqf property can be in the form of cooperation between countries in the scope of trannational as well as International, take for example; giving scholarship, donation of facillities and infrastructures for education through IDB Program (Islamic Development Bank).

\subsection{The Approach Concept in the Legal Reform of Waqf Dispute Resolution}

The legal reform of waqf dispute resolution always happen continously in order to finish the waqf disputes which become more complex, hence the waqf law can be enforced in society. It is done to fulfill the human being needs because law is aimed for human beings, and it is not human being for the law. The law does not appear for itself as being stated by Positif Law

\footnotetext{
30 Teuku Muhammad Radhie, "Pembangunan Hukum Nasional dalam Perspektif Kebijakan", dalam Artidjo AlKostar, Identitas Hukum Nasional, (Yogyakarta: Pustaka Pelajar Offset, 1997), 215.
} 
Science, but the law is aimed to reach the goal of human being prosperithy and happiness. This progresive law theory always position the law in the status of as law in the making. ${ }^{31}$

The big agenda of the legal reform of waqf dispute resolution is to harmonize between the law of waqf dispute resolution based on religion Principles with those based on national law. As a result the approcah concept uses the concept of law national development as stated by Mochtar Kusumaatmaja. He has formulated that the law does not include only the whole basics and principles which regulate the human being life in the society, but the law also includes the institutions and the processes that implement the rules of the law in the reality. ${ }^{32}$ Mochtar Kusumaatmaja views that the law is one system consisting of subsystems, namely ; the basics and the rules of the law, the law institutions and the process of law implementation. ${ }^{33}$ Therefore the law should be maintened in order to be enforced and implemented in the society. The national legal development should be directed to the planned efforts in order to: a) Improve the rules of law including adaptation with the world development without ignoring the awareness of law in the society; b) Bring into order the law institutions so that they are suitable with their own authorities; c) Improve the capability and the integrity of the law enforcers; d) Maintenance legal awareness in the society and fostering the attitude of goverment officials into the law enforcement, justice and protection for the human being dignity, law order and law certainty that are appropriate with the Rules.

The theory of law development as concepted by Mochtar Kusumaatmaja, if it is related to the legal reform of waqf dispute resolution,can be stated that goverment should create the policy in improving the rules of the law about the procedures of waqf dispute resolution in order to adjust with the demands of the era. So far, the rules of the law have not been implemented totally in the society as there are still some shortages in giving the guidance of procedure in waqf dispute resolution. Hence, the national policy in making regulation is very needed in order to reach the certainty of law so that the law can be enforced fairly in the society. These rules surely do not contradict with the other rules of the law and they do not leave the religious laws or the rules as the basic of waqf law implementation.

The nation should protect the rights of all waqf disputing parties and give the facillity and infrastructure in waqf dispute resolution which is in the form of waqf dispute in the society.

\footnotetext{
31 Satjipto Rahardjo, "Hukum Progresif: Hukum yang Membebaskan,” Jurnal Hukum Progresif 1, No. 1 (2015): 16.

32 Mochtar Kusumaatmaja, Op.Cit, 5.

33 Bernard Arief Sidharta, Refleksi Tentang Struktur Ilmu Hukum, (Bandung: Mandar Maju, 2017$), 7$.
} 
Therefore waqf disputes can be finished easily and it can create a good relationship after the disputes. Besides, the nation also improves the ability and the integrity of law enforcers of waqf law (PPAIW, nadzir, Religion Ministry officials in section of zakat and waqf) in order to be able to serve the needs of doing waqf including the procedures of waqf dispute resolution.

This research also uses approach concept of relationship between religious law and natioal law. Waqf law comes from religious law in the form of existing rules of the law in the society that will become alive and can be practiced in the society. Whereas the national law is the law that is determined by the national institution in order to give the certainty of law so that the people will get protection of law in the law action. According to Al-Ghazali, ${ }^{34}$ the relationship between religion and nation is like a twin. Religion is the basis in the goverment/authority, and the goverment should keep the religion. If nation without religion, the nation has no foundation and as a result it will be destroyed because it looses the values that are used as the base for thinking and doing. And the religion without nation will be useless since religion has no role in the life.

Related to the procedures of waqf dispute resolution, it needs the role of the nation in making the policy about the regulation of procedure in waqf dispute resolution in order that the society will be able to solve waqf dispute easily. Without the role of the nation, the waqf law can not be enforced and moreover waqf assets can not be saved, hence waqf law can not be implemented although it can take a role in the society. The resolution of waqf dispute fairly will support the role of waqf law in the society because it can help national policy in reaching the national development.

\section{Conclusion}

The legal reform of waqf dispute resolution is an important need because waqf dispute becomes more complex and varied. The Article 62 of the Waqf Rules does not explain in detail about discussion, mediation, amd arbritation, hence there is no law certainty used for practical guidance in procedures of waqf dispute resolution. Besides, the rules of waqf dispute resolution as stated in the Rules No. 30/1999 can not be applied because waqf doing has certain characteristic and so far the society apply the existing law that becomes a habit in solving waqf disputes. The objective of legal reform of waqf dispute resolution is to give law protection for the disputing parties, to save waqf treasures, to enforce the justice, the certainty of law and the

\footnotetext{
34 Al-Ghazali, Kimiya fi Sa'adat, Cet. 1, (Teheran, Iran 1940), 59.
} 
benefits. Moreover the rules of the law does not seem stiff, closed and authoritarian. The legal reform of waqf dispute resolution is done by the law which is based on Pancasila which contains prismatic law adjusted with the direction of national development policy and the goal of the nation. The procedure concept of its legal reform uses the theory of development law as stated by Mochtar Kusuma Atmaja and the theory of relationship between religious law and nation law as stated by al-Ghazali. Those two theories explain that the harmony between religious law and national law is needed for it can be a tool to reach the law development of the future without ignoring the values of the religion which contain the benefits.

\section{References}

Al-Ghazali. Kimiya fi Sa'adat. Cet. 1.Teheran, Iran, 1940.

Al-Kostar, Artidjo. Identitas Hukum Nasional. Yogyakarta: Pustaka Pelajar Offset, 1997.

At-Tanzil. Al-Qur'an dan Terjemahnya Juz 1 s/d 30 (Transliterasi). Bandung: Sinar Baru Algesindo, 2012.

BPS. "Persentase penduduk miskin Maret 2018 turun menjadi 9,82 persen." Badan Pusat Statistik. Accessed December 24, 2018, time 11.39 pm. https://www.bps.go.id/pressrelease/2018/07/16/1483/persentase-penduduk-miskin-maret2018-turun-menjadi-9-82-persen.html.

Fadhilah, Nur. "Sengketa Tanah Wakaf dan Strategi Penyelesaiannya."de Jure: Journal Syariah dan Hukum 3, No. 1 (2011): 71-85.

Government Regulation 42/2006 On Peraturan Pelaksanaan Wakaf.

Harahap, M. Yahya. "Informasi Materi Kompilasi Hukum Islam: Mempositifkan Abstraksi Hukum Islam.”Journal Mimbar Hukum 25, No. 3 (2010): 625-644.

Harahap, Sumuran. Paradigma Baru Wakaf. Jakarta: Direktorat Jendral Bimbingan Masyarakat Islam, Direktorat Pemberdayaan Wakaf, Kementrian Agama Republik Indonesia, 2006.

Hendrawati, Dewi dan Islamiyati. "Penyelesaian Sengketa Tanah Wakaf Yang Tidak Tersertifikasi Di Wilayah Pesisir Utara Jawa Tengah.”Journal Masalah- Masalah Hukum 47, No. 1 (2018): 71-80.

Hidayat, Arief. "Negara Hukum Pancasila (Suatu Model Ideal Penyelenggaraan Negara Hukum)," in Prosiding dalam Konggres Pancasila IV, Strategi Pelembagaan Nilai-Nilai Pancasila dalam Menegakkan Konstutusionalitas Indonesia. Yogyakarta: PSP UGM, 2012. 
Huda, Miftahul. “Arah Pembaharuan Hukum Wakaf di Indonesia.”Journal Studi Keislaman 16, No. $1: 125-145$.

Hurlburt William H. Law Reform Commissions in the United Kingdom. Australia and Canada: Juriliber, 1986

Ihromi, T. O. (Ed.). Antropologi Hukum:Sebuah Bunga Rampai.Jakarta: Yayasan Obor Indonesia, 2001.

Ismawati. Penyelesaian Sengketa Tanah Wakaf Studi Terhadap Tanah Wakaf Banda Masjid Agung Semarang, Thesis. Semarang: Magister Ilmu Hukum Diponegoro University, 2007.

Izzati Rizki Annisa. Efektivitas Mediasi Dalam Penyelesaiaan Sengketa Wakaf (Studi Kasus Tanah Wakaf Masjid Baitul Qudus Di Jalan Gebanganom Genuk Sari Semarang Jawa Tengah), Thesis, Ahwal As-Syakhsiyah Department, Faculty of Sharia and Law, Walisongo State Islamic University. Semarang: Walisongo State Islamic University, 2018. KHI Inpres 1/1991 Book III On Wakaf Law.

Komariah, Upi.“Penyelesaian Sengketa Wakaf Di Pengadilan Agama."Journal Hukum dan Peradilan 3, No. 2 (2014) : 117-126.

Kusuma Atmadja, Mochtar. Hukum, Masyarakat, dan Pembinaan Hukum Nasional. Jakarta; Bina Cipta, 1976.

Law 11/ 2012 On Pembentukan Peraturan Perundang-Undangan.

Law 41/ 2004 On Wakaf.

Moh. Mahfud. Membangun Politik Menegakkan Konstitusi. Jakarta: Rajawali Pers, 2010.

Rahardjo, Satjipto. "Hukum Progresif: Hukum yang Membebaskan.”Journal Hukum Progresif 1, No. 1 (2005): 1-24.

Santoso, Urip. "Penyelesaian Sengketa Wakaf Di Indonesia: Pendekatan Sejarah Sosial Hukum Islam, Kepastian Hukum Wakaf Tanah Hak Milik.” Journal Perspektif 14, No. 2 (2014): 71-80.

Sayyid Abi Bakar bin Sayyid Muhammad, I'anah al-Thalibin, Juz III, Beirut: Da>r al-Kutub alIlmiah, without year.

Sidharta, Bernard Arief.Refleksi Tentang Struktur Ilmu Hukum. Bandung: Mandar Maju, 2017.

Siregar, Ibrahim."Penyelesaian Sengketa Wakaf Di Indonesia: Pendekatan Sejarah Sosial Hukum Islam.” Journal Miqot 36, No. 1 (2012): 122-137.

Soedarto. Hukum dan Hukum Pidana. Bandung: Alumni, 1986. 
Suchmadi.“Kajian Undang-Undang Nomor 41 Tahun 2004 Tentang Wakaf (Metode Pembaruan Hukum Wakaf di Indonesia).”Accested April 9, 2018. http://id.portalgaruda.org/?ref=browse \&mod=viewarticle \&article=401702.

Syufa'at. "Penerapan Prosedur Mediasi Dalam Penyelesaian Sengketa Wakaf di Pengadilan Agama."Journal Volksgeist 1, No. 1 (2018): 21-36. 